Pig Housing and the Environment

Occasional Publication No. 11-British Society of Animal Production 1987

edited by A. T. Smith and T. L. J. Lawrence

\title{
A WET SCRUBBER FOR CONTROL OF AERIAL POLLUTION IN INTENSIVE LIVESTOCK HOUSING
}

\author{
C. C. PEARSON
}

Farm Buildings Group, Land and Water Service, MAFF, Government Buildings, Coley Park, Reading, Berkshire

$\mathbf{P}$ revious research has shown that reduction in concentrations of dust, microbes, ammonia $\left(\mathrm{NH}_{3}\right)$ and carbon dioxide $\left(\mathrm{CO}_{2}\right)$ improve the health of intensively housed livestock and the people who work with them. Some improvements in productivity have also been noted.

Several methods of removing these pollutants have been tried including dry filtration, electrostatic filtration, ionization and increased ventilation. All are successful in some applications for one or more of the pollutants but have disadvantages such as frequent clogging.

A wet scrubber should be capable of removing dust, microbes, $\mathrm{NH}_{3}$ and $\mathrm{CO}_{2}$ and disposing of the debris continuously with little or no human intervention. We decided to design one suitable for intensive livestock buildings, assess and optimize its performance.

A wet scrubber is basically a device for passing polluted air through water to clean the air. Two common ways of achieving this are a water spray and a packed tower. The wet scrubber we designed comprised, in order of air flow: a large droplet zone for removal of large dust particles, a packed tower for absorption of gases and a water spray for removal of smaller particles. Air flow rate was $0.8 \mathrm{~m}^{3} / \mathrm{s}$.

It was installed in a 240 place pig fattening unit and assessed over the winter of $1985 / 86$. The aims of the tests were:

(1) to establish the viability of a wet scrubber for removing air pollutants in intensive livestock housing;

(2) to find the optimum combination of water recirculation and replenishment;

(3) to investigate the effect of ultra violet (u.v.) light on the survival of bacteria; and

(4) to measure the efficiency of removal of the four pollutants identified.

No attempt was made to study the effects on the livestock although weight gains were noted.

Water recirculation and replenishment and u.v. lamp status were changed weekly. Measurements were made at the end of each week. Temperature, humidity and pollutant concentrations were measured at the inlet and outlet of the scrubber. Bacterial colony-forming particles (BCFP) were counted using a general medium in an Anderson sampler. Specific media were also used on two occasions. $\mathrm{CO}_{2}$ and $\mathrm{NH}_{3}$ were measured using time weighted average chemical reagent (Draeger) tubes and a diaphragm pump.

Dust concentrations were reliably measured on two occasions with a gravimetric method using $6-\mathrm{cm}$ glass fibre filter papers and a $30 \mathrm{l} / \mathrm{min}$ pump. The percentage reductions of the four pollutants are shown in Table 1 .

TABLE 1

Percentage reduction of the four pollutants

\begin{tabular}{|c|c|c|}
\hline & Average & $\begin{array}{l}\text { Best water flow } \\
\text { rate }\end{array}$ \\
\hline Dust & 91 & 94 \\
\hline BCFP & 37 & 54 \\
\hline $\mathrm{NH}_{3}$ & 22 & 30 \\
\hline $\mathrm{CO}_{2}$ & 12 & 21 \\
\hline
\end{tabular}

No significant variations in performance could be attributed to the controlled variables. There was a tendency to better performance at $0.1261 / \mathrm{s}$ recirculation for $\mathrm{CO}_{2}$ and $0.0791 / \mathrm{s}$ for other pollutants. Reduction in BCFP was slightly better when u.v. lamp was in use, $42 \%$ as opposed to $32 \% . \mathrm{CO}_{2}$ and $\mathrm{BCFP}$ reduction was greater at low and $\mathrm{NH}_{3}$ reduction at high, water replenishment rates. The tests showed that the scrubber is effective at reducing levels of four pollutants. It performed continuously for 5 months with only weekly cleaning of the water strainer. Optimum rates of water recirculation and replenishment were not conclusively determined but some indication of suitable rates was found.

Future work will include optimization of the scrubber configuration, installation of larger scrubbers, installation in other agricultural buildings and clinical assessment of the effect on livestock. 